\title{
Heterogeneity of resting and hyperemic myocardial blood flow in healthy volunteers: a quantitative CMR perfusion pixel-map study
}

\author{
Anders M Greve ${ }^{1 *}$, Li-Yueh Hsu', Sujethra Vasu², W Patricia Bandettini ${ }^{1}$, Andrew E Arai ${ }^{1}$ \\ From 17th Annual SCMR Scientific Sessions \\ New Orleans, LA, USA. 16-19 January 2014
}

\section{Background}

An accurate description of the heterogeneity in myocardial blood flow (MBF) by CMR is needed for understanding the physiology of perfusion variability.

\section{Methods}

Quantitative CMR perfusion was performed at $1.5 \mathrm{~T}$ in 17 healthy volunteers under baseline (rest) and adenosine hyperemia (stress). Median filters with different kernel size were used to estimate MBF at different resolutions $(0.07 \mathrm{~g}, 0.27 \mathrm{~g}, 0.61 \mathrm{~g}, 1.1 \mathrm{~g}$ of myocardium). MBF heterogeneity was evaluated as the relative dispersion $([R D]=$ standard deviation/mean $)$ on basal- and mid-ventricular slices for each subject. Paired t-tests and linear mixed-models were used to account for withinsubject effects.

\section{Results}

All normal volunteers had Framingham scores $<1 \%$. $\mathrm{MBF}$ at rest was $1.1 \mathrm{ml} / \mathrm{g} / \mathrm{min}(95 \% \mathrm{CI}: 0.9$ to $1.2 \mathrm{ml} / \mathrm{g} /$ $\mathrm{min}$ ) vs. adenosine stress $2.8 \mathrm{ml} / \mathrm{g} / \mathrm{min}$ (95\% CI: 2.4 to $3.1 \mathrm{ml} / \mathrm{g} / \mathrm{min}[\mathrm{p}<0.001])$. At the intrinsic image acquisition resolution ( 1 voxel $=0.07 \mathrm{~g})$, the $\mathrm{RD}$ was $13.0 \%$ (95\% CI: 11.7 to $14.3 \%$ ) at rest vs. $15.9 \%$ (95\% CI: 14.1 to $17.7 \%)$ at adenosine stress $(\mathrm{p}=0.004)$. For increasing voxel sizes, the RD of MBF under rest and stress conditions decreased in a highly-significant pattern (Figure 1). There were no detectable differences in pairwise comparisons of RD between basal and mid-slices at rest or under hyperemic conditions (all $\mathrm{p}=\mathrm{NS}$ ).

\footnotetext{
'Department of Health and Human Services, Advanced Cardiovascular Imaging Laboratory, National Heart, Lung, and Blood Institute, National Institutes of Health, Bethesda, Maryland, USA

Full list of author information is available at the end of the article
}

\section{Conclusions}

Healthy myocardium displays resolution-dependent hetereogeneity of $\mathrm{MBF}$ at rest that increases during hyperemia. MBF heterogeneity by quantitative CMR is lower than that reported by microsphere data for equal tissue weight. Furthermore, this analysis is, to the best of our knowledge, 4 times higher resolution than any microsphere or PET analysis.

\section{Funding}

This project was funded by the Intramural research program of the National Heart Lung and Blood Institute at the National Institutes of Health.

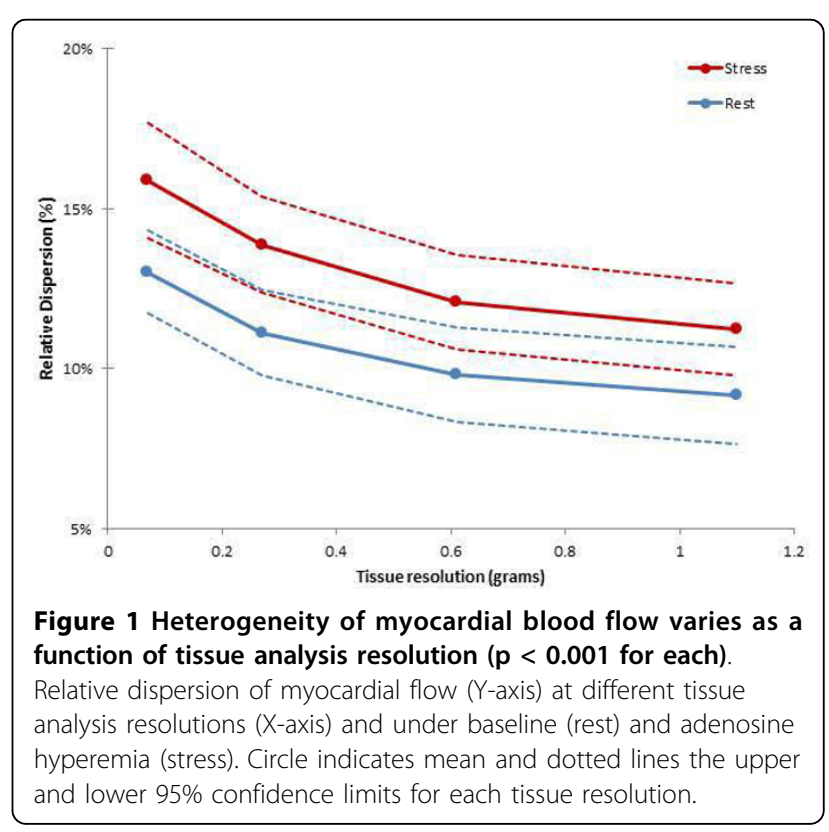




\section{Authors' details}

${ }^{1}$ Department of Health and Human Services, Advanced Cardiovascular Imaging Laboratory, National Heart, Lung, and Blood Institute, National Institutes of Health, Bethesda, Maryland, USA. ${ }^{2}$ Section of Cardiology, Wake Forest University School of Medicine, Winston-Salem, North Carolina, USA.

Published: 16 January 2014

doi:10.1186/1532-429X-16-S1-P21

Cite this article as: Greve et al:: Heterogeneity of resting and hyperemic myocardial blood flow in healthy volunteers: a quantitative CMR

perfusion pixel-map study. Journal of Cardiovascular Magnetic Resonance 2014 16(Suppl 1):P21.

Submit your next manuscript to BioMed Central and take full advantage of:

- Convenient online submission

- Thorough peer review

- No space constraints or color figure charges

- Immediate publication on acceptance

- Inclusion in PubMed, CAS, Scopus and Google Scholar

- Research which is freely available for redistribution

Submit your manuscript at www.biomedcentral.com/submit 